\title{
Quantitative assessment of organosulfates in size-segregated rural fine aerosol
}

\author{
H. Lukács, A. Gelencsér, A. Hoffer, G. Kiss, K. Horváth, and Z. Hartyáni \\ Department of Earth and Environmental Sciences, Air Chemistry Group of the Hungarian Academy of Sciences University of \\ Pannonia, Veszprém, Hungary
}

Received: 5 March 2008 - Published in Atmos. Chem. Phys. Discuss.: 9 April 2008

Revised: 9 December 2008 - Accepted: 9 December 2008 - Published: 14 January 2009

\begin{abstract}
Organosulfates have recently come into the focus of organic aerosol research as potentially important components of water-soluble secondary organic aerosol (SOA) which now dominate tropospheric fine aerosol. Their presence has been confirmed by the identification of sulfate esters of abundant biogenic carbonyl compounds in both smog chamber and continental aerosol. However, none of the studies have been able to determine the mass contribution of organosulfates to SOA.

In this paper, as possibly the very first attempt to quantify organosulfates in ambient aerosol, we inferred the mass concentrations of organosulfates by concurrently determining mass concentrations of total sulfur, sulfate and methanesulfonate in rural fine aerosol using two highly sensitive analytical techniques. Although uncertainties were relatively large, we found that mass concentrations of organosulfates in water-soluble fine aerosol ranged from $0.02 \mu \mathrm{gS} \mathrm{m}^{-3}$ to $0.09 \mu \mathrm{gS} \mathrm{m}^{-3}$ yielding a mass contribution of $6-12 \%$ to bulk sulfur concentrations (or 6-14\% to sulfate concentrations). The inferred size distribution of organosulfates suggested that they possibly form in heterogeneous reactions from semi-volatile carbonyl compounds with subsequent or concurrent condensation of gaseous sulfuric acid producing a refractory organic film on particle surfaces.
\end{abstract}

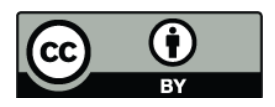

Correspondence to: A. Gelencsér (gelencs@almos.uni-pannon.hu)

\section{Introduction}

Organic aerosol is now a major constituent of tropospheric fine aerosol and its effects are becoming increasingly important in determining climatic and other effects of atmospheric aerosol. A significant fraction of organic aerosol is formed in the atmosphere as secondary organic aerosol (SOA) (Kroll and Seinfeld, 2008). It is generally agreed that current atmospheric models based on the traditional concepts of SOA formation severely underestimate SOA mass concentrations observed in most parts of the troposphere. Ten years ago it was already suggested that besides photooxidation of volatile organic compounds and subsequent gas-to-particle partitioning of semi- or less volatile oxidation products, heterogeneous and multiphase processes may play an important yet poorly understood role in SOA formation (Ravishankara, 1997). Since then, significant progress has been made in these fields, and our understanding regarding the importance of these processes in the atmosphere has been improving.

It has been shown quite recently that heterogeneous reactions involving acidic seed aerosol significantly enhance secondary organic aerosol (SOA) yields in controlled smog chamber experiments (Jang and Kamens, 2001; Jang et al., 2002). The volatile organic compounds involved in such studies were well-known aerosol precursors such as $\alpha$-pinene (Czoschke et al., 2003; Gao et al., 2004a, b; Iinuma et al., 2004; Tolocka et al., 2004; Kleindienst et al., 2006; Czoschke and Jang, 2006; Jang et al., 2006), $\beta$-pinene (Iinuma et al., 2007b; Northcross and Jang, 2007), limonene (Iinuma et al., 2007a; Northcross and Jang, 2007), and isoprene (Czoschke et al., 2003; Edney et al., 2005; Surratt et al., 2006; Surratt et al., 2007b), or directly their semi-volatile photooxidation products like pinonaldehyde (Liggio and $\mathrm{Li}$,

Published by Copernicus Publications on behalf of the European Geosciences Union. 
2006a, b), glyoxal (Kroll et al., 2005; Liggio et al., 2005), or other carbonyls (Jang et al., 2003, 2004, 2005). In the case of hydroxy compounds organosulfates are formed by esterification with sulfuric acid, while in the case of carbonyl compounds esterification occurs after gem-diol formation. Similar reactions can be induced by photooxidation of aerosol precursors and $\mathrm{SO}_{2}$ (Surratt et al., 2007). It has been shown recently that on highly acidic particles even the direct uptake of isoprene and $\alpha$-pinene is possible, i.e. without any prior photooxidation step (Liggio et al., 2007), confirming the hypothesis based on previous bulk experiments (Limbeck et al., 2003).

Albeit the mechanisms behind the enhanced uptake are still largely unknown, recent mass spectrometric evidence suggests that organosulfate (sulfate esters and their derivatives) formation is involved (Surratt et al., 2007). Such compounds have been detected in limonene photooxidation experiments in which no apparent increase in SOA yield was detected with increasing seed acidity (Iinuma et al., 2007a). Matrix-assisted laser desorption ionizationmass spectrometry (MS) measurements conducted on smogchamber aerosol indicated that sulfate diester formation or sulfate ester oligomerization reactions may also be possible (Surratt et al., 2007); however, Iinuma et al. (2007b) provided conclusive mass spectrometric evidence for the presence of sulfate diester formation in $\beta$-pinene SOA (i.e. the esterification of two $\beta$-pinene oxidation products with one sulfuric acid molecule). It was also demonstrated in smog-chamber experiments that high $\mathrm{NO}_{\mathrm{x}}$ mixing ratios strongly suppressed organosulfate formation possibly because organic acid formation was favored at the expense of esterification reactions (Surratt et al., 2007).

It has also been shown that organosulfates are thermally stable even at the high temperatures of the analytical instruments and do not interfere with ion chromatographic inorganic sulfate measurements (Liggio and Li, 2006; Surratt et al., 2007), but partially revert to inorganic sulfate during detection in aerosol mass spectrometry (Liggio and $\mathrm{Li}, 2006$ ). For isoprene, enhancement of sulfate ester signals in the presence of acidic seed aerosol was largely in the same order as in previous SOA yield observations (Surratt et al., 2007). As an additional indirect evidence, inorganic sulfate was shown to decrease in line with the emergence of organosulfate signals. Additional experiments excluded that organosulfates can be sampling or measurement artifacts (Surratt et al., 2007).

In addition to smog-chamber studies, a few field measurements indicated the presence of specific sulfate esters (also identified in follow-up smog-chamber studies) using Liquid Chromatography Electrospray Ionisation Tandem Mass Spectrometry (LC-ESI-MS) (Gao et al., 2006; Surratt et al., 2007; Iinuma et al., 2007b), or the presence of organosulfur functional groups by Fourier Transform Infrared Spectroscopy (FTIR) (Blando et al., 1998; Gilardoni et al., 2007) implying that the chemistry occurring in smog-chamber experiments may be relevant under ambient conditions in spite of the significantly lower VOC (volatile organic compounds) mixing ratios, higher RH and possibly lower aerosol acidity. A recent study on water-soluble HULIS (Humic Like Substances) fraction of urban and rural aerosol also suggested that organosulfates are present in the high MW fraction of the organic aerosol as well (Romero and Oehme, 2005). ESI in combination with ultra high resolution Fourier transform ion cyclotron resonance (FT-ICR) mass spectrometry implied the presence of a large number of sulfur containing organic compounds (Reemtsma et al., 2006). Similarly, ESI combined with FT-ICR-MS with even higher mass resolution has been applied for rural aerosol collected under conditions conducive to photochemical smog formation and identified a large number of water-soluble organic compounds containing one sulfur atom (Schmitt-Kopplin et al., manuscript in preparation). Very recently, sulfate esters of the gem-diol form of the photooxidation products of isoprene (e.g. glyoxal and methylglyoxal) and of unsaturated fatty acids (2-hydroxy-1,4-butanedialdehyde) have been identified in $\mathrm{PM}_{2.5}$ aerosol collected at K-Puszta (Gómez-González et al., 2008).

Among other potential sulfur compounds methanesulfonate (MSA) is by far the most abundant species which is formed in the photooxidation of dimethylsulfide (DMS) (von Glasow and Crutzen, 2004). However, this compound was reported to occur in concentrations in the order of 60$110 \mathrm{ng} \mathrm{m}^{-3}$ (corresponding to sulfur-equivalent mass concentrations of $20-37 \mathrm{ngS} \mathrm{m}^{-3}$ ) predominantly in the marine atmosphere (Quinn et al., 2000; Kouvarakis and Mihalopoulos, 2002; Mihalopoulos et al., 2007). Continental measurements of MSA are sparse, but a recent study conducted reported mass concentrations of MSA, if detected at all, around $10 \mathrm{ngS} \mathrm{m}^{-3}$ (Ocskay et al., 2006). This makes it very likely that organosulfates are quantitatively the most important components among water-soluble organic sulfur compounds.

Despite the emerging evidence from both smog-chamber studies and ambient aerosol measurements that organosulfates may explain a significant part of the hitherto unknown fraction of SOA, all of the studies made so far have lacked the quantitative aspect how important this class of compounds can be on a mass basis. This is because the mass spectrometric techniques used in the above studies to assign chemical structures or even exact elemental composition of specific sulfur containing compounds are not suitable to determine mass concentrations of individual compounds when standards are not available, or of organic sulfur in bulk. Without this information, however, it is very difficult to assess the contribution of organosulfates to atmospheric SOA, and to incorporate them into atmospheric models. Thus the magnitude of the effects these compounds likely play in the troposphere remains essentially unknown.

In this study we used two highly sensitive analytical techniques to determine mass concentrations of total (bulk) sulfur and both sulfate and methanesulfonate ions concurrently in 
aqueous extracts of size-segregated rural aerosol. The mass concentrations of organic sulfur were inferred as a difference between the results of two independent measurements. Extreme care was taken to minimize the discrepancies between the two methods, and uncertainties were carefully evaluated. To the best of our knowledge, our method is the first attempt to quantitatively assess the contribution of organosulfates to both SOA and sulfate aerosols.

\section{Experimental}

\subsection{Sampling and sample preparation}

Aerosol samples were taken in May and June 2006 at Kpuszta, Hungary. The Hungarian background air-pollution monitoring station, K-puszta is situated on a forest clearing of the Great Hungarian Plain, $136 \mathrm{~m}$ a.s.l. Since the station is located in a confined area relatively far from anthropogenic sources (the only nearby town is about $15 \mathrm{~km} \mathrm{SE}$ from the station while the prevailing wind direction is WNW) samples collected at K-puszta likely represent the Central European regional air.

Aerosol samples were taken for 48 hours with an 8-stage Berner impactor with cut-off sizes from 0.0625 to $16 \mu \mathrm{m}$ $(0.0625,0.125,0.25,0.5,1,2,4,8,16 \mu \mathrm{m})$. Since organosulfates are assumed to be secondary aerosol constituents and all related smog-chamber experiments were confined to the fine aerosol mode, in this work we focussed only on particles smaller than $2 \mu \mathrm{m}$ diameter (impactor stages $1-5$ ). The air was sampled at a height of $10 \mathrm{~m}$ above the surface under ambient conditions, at a flow rate of $1.878 \mathrm{~m}^{3} \mathrm{~h}^{-1}$. The aerosol samples were collected on pre-cleaned $\mathrm{Al}$-foils and stored in the freezer until analysis.

One quarter of each Al-foil was extracted with $2 \mathrm{ml}$ Milli$\mathrm{Q}$ water for $24 \mathrm{~h}$. The extracts were filtered through MillexHV Durapore membrane filters $(0.22 \mu \mathrm{m}$ pore diameter $)$ in order to remove particles suspended in the solutions. The extracts were divided in two for further analyses.

\subsection{Analytical methods}

Water soluble total sulfur $\left(\mathrm{S}_{\text {total }} \mu \mathrm{gS} \mathrm{m}^{-3}\right)$, sulfate ions

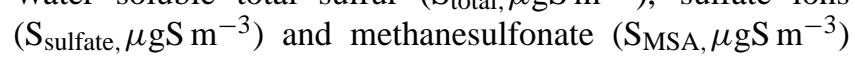
concentrations were determined in aqueous aerosol extracts by two independent methods. In order to minimize the possible biases of sampling and sample handling, the very same extract was simultaneously analyzed by the two methods which were calibrated using the same standard solution. These precautions were necessary since the mass concentrations of organic sulfur were obtained as a difference between the two relatively large values of measured concentrations. Although the relative estimates are not affected, absolute concentrations might be loaded with an additional bias which arose from the fact that the measurements were taken from one quarter of each impactor plate.

\subsubsection{Determination of $\mathrm{S}_{\text {sulfate }}$ and $\mathrm{S}_{\mathrm{MSA}}$}

Mass concentrations of sulfate and methanesulfonate ions were analyzed by ion chromatography. The aerosol extracts were injected directly without any further preparation.

All the reagents employed were of analytical grade (Fluka Chemie AG, Buchs, Switzerland). All aqueous solutions were prepared in high purity water $\left(18.2 \mathrm{M} \Omega \mathrm{cm}^{-1}\right.$ resistivity) obtained with a Milli-Q Plus apparatus (Millipore, Bedford, MA, USA).

Ion chromatographic measurements were performed with a Dionex DX300 gradient chromatographic system (Dionex, Sunnyvale, CA, USA), which consisted of a CHA-6 high pressure chromatographic module, Dionex EDM eluent degas module, gradient pump and a conductivity detector CDM-II. Chromatograms were recorded digitally using Dionex ACI advanced computer interface and Dionex AI 450 software. Model 9125 injection unit (Rheodyne, Rohnert Park, CA, USA) was applied containing a $100 \mu \mathrm{l}$ injection loop. Separations were carried out on a Dionex IonPac AS9-HC, $250 \times 4 \mathrm{~mm}$, analytical column with a capacity of $190 \mu$ eq. The column substrate was a $9 \mu \mathrm{m}$ diameter macroporous ( $2000 \AA$ ) resin bead, consisting of ethylvinylbenzene crosslinked with 55\% divinylbenzene. The anion exchange layer was functionalized with quaternary ammonium groups.

This anion exchange layer had a controlled thickness. $11 \mathrm{mM}$ sodium carbonate solution was used as an eluent which was stored under $\mathrm{He}$ atmosphere and was prepared daily. The conductivity of the eluent was suppressed with a Dionex AMMS-II suppressor continuously regenerated by $25 \mathrm{mM}$ sulfuric acid with a flow rate of $3.5 \mathrm{ml} \mathrm{min}^{-1}$. All samples were analyzed in triplicate with a flow rate of $1 \mathrm{ml} \mathrm{min}^{-1}$.

Sensitivity of the method for sulfate ions was $138.53 \mu \mathrm{Spm}^{-1} \mathrm{~S}$, Lower Limit of Detection (LLD) was $0.09 \mathrm{ppmS}, R^{2}$ value of the analytical curve was 0.999 . RSD values varied between 1.3 and $7.8 \%$, (average $2.3 \%$ ).

Since formate and methanesulfonate co-eluted under the conditions of separation (Fig. 1) the determination of mass concentrations of methanesulfonate required the resolution of the two overlapping peaks. The resolution was carried out by fitting exponentially modified Gaussian (EMG) functions on the envelope of overlapping peak profiles. The parameters of EMG curves described the shape of the individual formate and methanesulfonate peaks were determined prior to the calculations. The determined values then were used as initial parameters during the mathematical resolution of peaks of formate and methanesulfonate (Felinger, 1998). The concentrations of methanesulfonate in the samples were calculated on the basis of the calculated area of the resolved peak of this component. 
Table 1. Total mass concentrations of total (bulk) sulfur $\left(\mathrm{S}_{\text {total }}, \mu \mathrm{gS} \mathrm{m}{ }^{-3}\right)$, sulfate $\left(\mathrm{S}_{\text {sulfate }}, \mu \mathrm{gS} \mathrm{m}^{-3}\right)$ and methanesulfonate ions $\left(\mathrm{S}_{\mathrm{MSA}}, \mu \mathrm{gS} \mathrm{m}^{-3}\right)$ and organosulfates, with corresponding relative standard deviations (see discussion below for details) $\left(\mathrm{S}_{\mathrm{org}}, \mu \mathrm{gS} \mathrm{m}^{-3}\right)$, and the ratio of organosulfates to total (bulk) sulfur and to sulfate ions [\%] (with relative standard deviations) in aqueous extracts of fine aerosol samples collected at K-puszta (Hungary) in May and June 2006.

\begin{tabular}{|c|c|c|c|c|c|c|c|c|c|c|c|c|}
\hline \multirow[t]{2}{*}{ Sampling period } & \multicolumn{2}{|c|}{$\mathrm{S}_{\text {total }}$} & \multicolumn{2}{|c|}{$S_{\text {sulfate }}$} & \multicolumn{2}{|c|}{$\mathrm{S}_{\mathrm{MSA}}$} & \multicolumn{2}{|c|}{$S_{\text {org }}$} & \multicolumn{2}{|c|}{$\mathrm{S}_{\text {org }} / \mathrm{S}_{\text {total }}$} & \multicolumn{2}{|c|}{$\mathrm{S}_{\text {org }} / \mathrm{S}_{\text {sulfate }}$} \\
\hline & $\begin{array}{c}\text { average } \\
{\left[\mu \mathrm{gS} \mathrm{m}^{-3}\right]}\end{array}$ & $\begin{array}{c}\mathrm{RSD}[\%] \\
{[\%]}\end{array}$ & $\begin{array}{c}\text { average } \\
{\left[\mu \mathrm{gS} \mathrm{m}^{-3}\right]}\end{array}$ & $\begin{array}{c}\mathrm{RSD}[\%] \\
{[\%]}\end{array}$ & $\begin{array}{c}\text { average } \\
{\left[\mu \mathrm{gS} \mathrm{m}^{-3}\right]}\end{array}$ & $\begin{array}{c}\mathrm{RSD}[\%] \\
{[\%]}\end{array}$ & $\begin{array}{c}\text { Average } \\
{\left[\mu \mathrm{gS} \mathrm{m}^{-3}\right]}\end{array}$ & $\begin{array}{c}\text { RSD } \\
{[\%]}\end{array}$ & $\begin{array}{c}\text { average } \\
{[\%]}\end{array}$ & $\begin{array}{c}\text { RSD } \\
{[\%]}\end{array}$ & $\begin{array}{c}\text { average } \\
{[\%]}\end{array}$ & $\begin{array}{r}\mathrm{RSD} \\
{[\%]}\end{array}$ \\
\hline 29-31 Мay & 0.57 & 6.7 & 0.50 & 2.4 & 0.010 & 14 & 0.06 & 63 & 11 & 64 & 13 & 63 \\
\hline 4-6 June & 0.70 & 6.8 & 0.60 & 2.5 & 0.012 & 14 & 0.09 & 58 & 12 & 58 & 14 & 58 \\
\hline 6-8 June & 0.70 & 7.0 & 0.63 & 2.5 & 0.013 & 15 & 0.05 & 96 & 7.7 & 96 & 8.5 & 96 \\
\hline 14-16 June & 0.38 & 7.3 & 0.35 & 2.4 & 0.007 & 14 & 0.02 & 129 & 5.9 & 129 & 6.4 & 129 \\
\hline
\end{tabular}

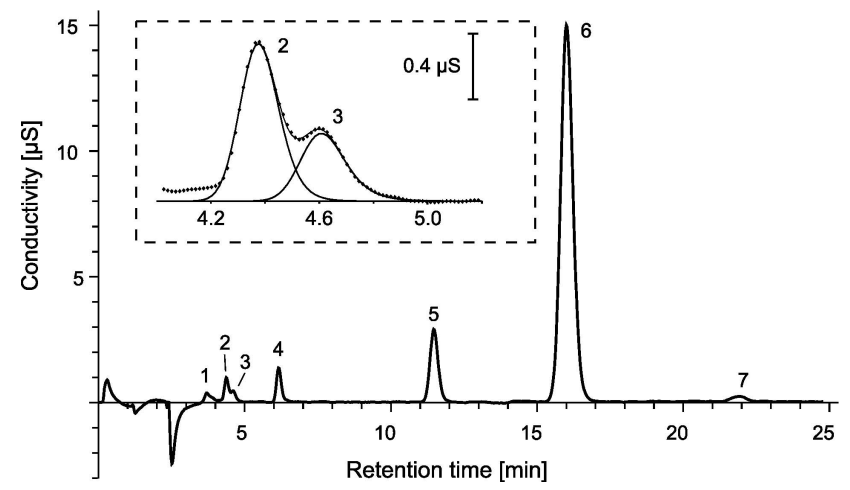

Fig. 1. Ion chromatogram of the aqueous aerosol extract $(0.25-$ $0.5 \mu \mathrm{m}$ particle diameter) from the sample collected between $6-8$ June, 2006. Peaks: 1: unknown, 2: formate, 3: methanesulfonate, 4: chloride, 5: nitrate, 6: sulfate, and 7: oxalate. The peaks of formate and methanesulfonate resolved by curve fitting can be seen in the dashed box.

Sensitivity of the method for methanesulfonate was $1.14 \mu \mathrm{Sppm}^{-1} \mathrm{~S}$, the estimated Lower Limit of Detection (LLD) was $0.18 \mathrm{ppmS}, R^{2}$ value of the analytical curve was 0.999 . RSD values varied between 0.7 and $9.6 \%$ (average $5.1 \%)$.

\subsubsection{Determination of $S_{\text {total }}$}

Mass concentrations of water soluble total sulfur $\left(\mathrm{S}_{\text {total }}\right)$ were determined by a sensitive X-Ray fluorescence spectrometric (XRF) method which was developed for direct analysis of the chemical composition of aerosol samples (Szilágyi et al., 2004).

A PHILIPS PW 2404 wavelength dispersive X-ray fluorescence spectrometer equipped with a $4 \mathrm{~kW} \mathrm{Rh}$ anode tube $(32 \mathrm{kV}, 125 \mathrm{~mA})$ was applied, flow counter was used as a detector, the collimator was $300 \mu \mathrm{m}$, while the analyzing crystal was Ge $111-\mathrm{C}$, with $2 \Theta$ Bragg angle of $110.52^{\circ}$. Total counting time on $\mathrm{S} \mathrm{K} \alpha$ line was $40 \mathrm{~s}$.
A liquid sample holder with $6 \mu \mathrm{m}$ thick Mylar foil was placed in a steel sample holder cup with an inner diameter of $27 \mathrm{~mm}$. Both standards and samples to be analyzed were applied facing the X-ray source and covered with a Re plate. Applying Re plate as a secondary target resulted in increased sensitivity of the $\mathrm{SK} \alpha$ line.

$250 \mu \mathrm{l}$ of the aerosol extracts was applied on fixed sized Al-foils and dried at room temperature in a closed glass box under a gentle flow of nitrogen. Calibration was performed in triplicate with standard solutions of $\mathrm{Na}_{2} \mathrm{SO}_{4}$ in the range of $0-1.5 \mu \mathrm{gS}$ absolute. Sensitivity of the method was 1.69 $\mathrm{kcps} \mu \mathrm{gS}^{-1}$, Lower Limit of Detection (LLD) was $0.01 \mu \mathrm{gS}$. $R^{2}$ value of the analytical curve was 0.995 , RSD values varied between 2 and $11 \%$ (average $6 \%$ ) except for the blank for which the RSD was $27 \%$.

\subsubsection{Estimation of uncertainties}

The relative standard deviations of the measurements were determined experimentally for each analyte and each impactor stage. The RSD of sulfate and methanesulfonate mass concentrations were determined from triplicate measurements of the extract of each impactor stage. The RSD accompanying total sulphur mass concentrations determined by XRF from the very same extract was estimated from triplicate measurements of the calibration solutions nearest in concentration to that of each sample due to the fact that the volume of the extract did not allow replicate measurements. The RSD values of organic sulfur mass concentrations that were inferred as the difference between measured quantities were calculated using the statistical rules of error propagation. The same statistical methods were used in calculating the total submicron mass concentrations by addition of measured mass concentrations of the respective impactor stages. 

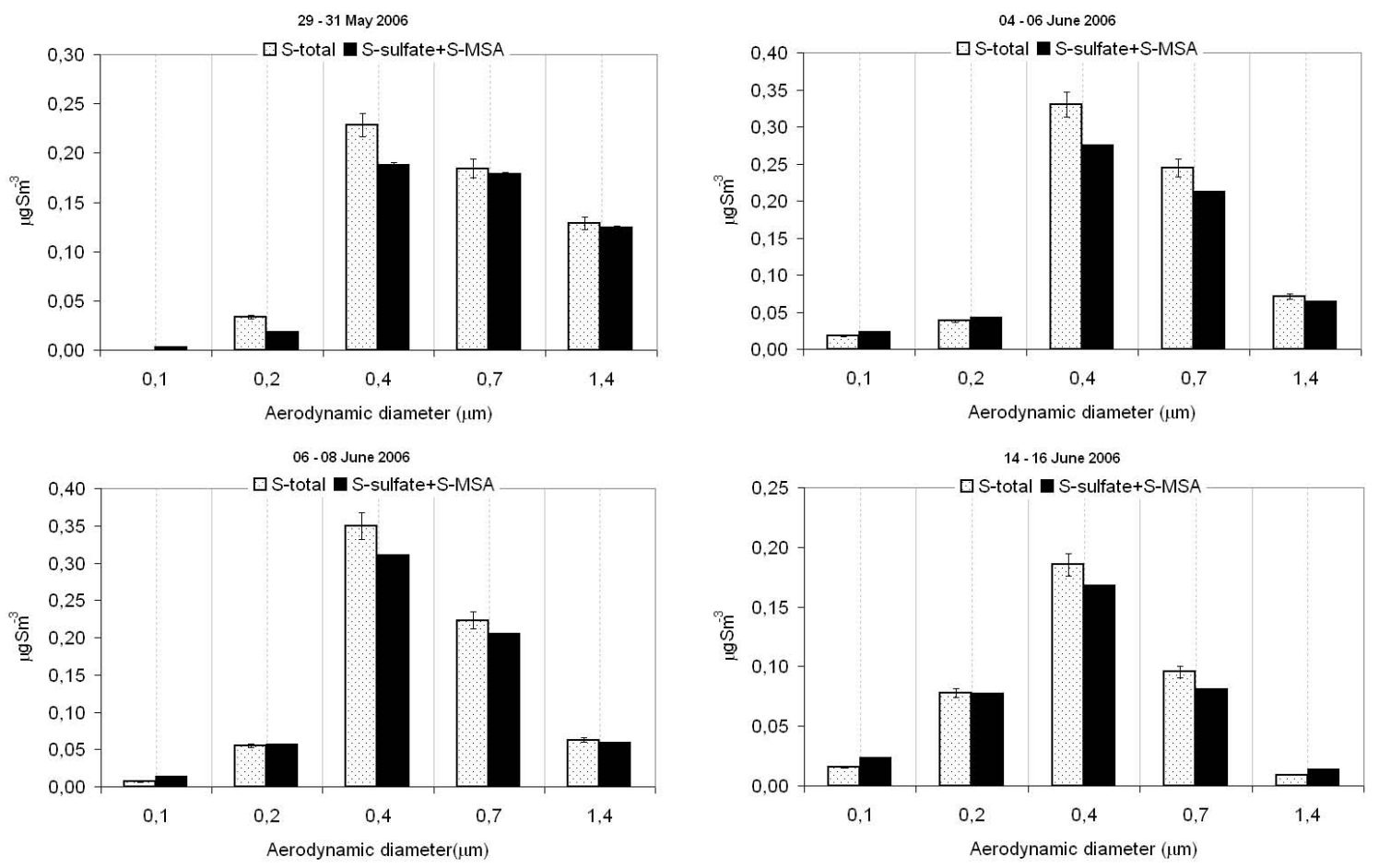

Fig. 2. Measured mass concentrations total (bulk) sulfur and sulfate plus methanesulfonate ions on submicron impactor stages $\left[\mu \mathrm{gS} \mathrm{m}^{-3}\right]$, in aqueous extracts of aerosol samples collected at K-puszta (Hungary) in May and June 2006. The error bars represent the corresponding relative standard deviation.

\section{Results and discussion}

\subsection{Mass concentration of organosulfates}

The concentrations of $\mathrm{S}_{\text {total }}, \mathrm{S}_{\text {sulfate }}, \mathrm{S}_{\mathrm{MSA}}$ reported in Table 1 were calculated as a sum of the concentrations measured in each impactor stage.

Mass concentrations of organic sulfur $\left(\mathrm{S}_{\text {org }}, \mu \mathrm{gS} \mathrm{m}{ }^{-3}\right)$ were estimated as the sum of differences between the mass concentrations of total sulfur $\left(\mathrm{S}_{\text {total }}, \mu \mathrm{gS} \mathrm{m}^{-3}\right)$ and of sulfate $\left(\mathrm{S}_{\text {sulfate }}, \mu \mathrm{gS} \mathrm{m}^{-3}\right)$ and methanesulfonate $\left(\mathrm{S}_{\mathrm{MSA}}, \mu \mathrm{gS} \mathrm{m}^{-3}\right.$ ) ions in aqueous extracts of the five impactor stages of each sample. As shown in Table 1, mass concentrations of organic sulfur in fine aerosol ranged from $0.02 \mu \mathrm{gS} \mathrm{m}^{-3}$ to $0.09 \mu \mathrm{gS} \mathrm{m}^{-3}$ representing $6-12 \%$ of bulk sulfur concentrations (or $6-14 \%$ of sulfate concentrations). The RSD values of the total submicron organic sulfur mass concentrations were relatively high since they were calculated as the difference of two large measured quantities, and were loaded with additional uncertainty resulting from the mathematical operations. In spite of the relatively high RSD values of the organosulfate concentrations, it can be clearly seen that its concentration is not negligible in the summer-time fine aerosol in K-puszta. An additional error might be caused by particle bounce/loss on $\mathrm{Al}$ foil but it would probably affect sulfate and organosulfate mass on each stage equally since the most particles are internally mixed.
In our method the mass concentration of water-soluble organic sulfur was indirectly estimated as the difference between the sulfur-equivalent mass concentrations of total sulfur and sulfate plus methanesulfonate, but there was no explicit information on the chemical character of the compounds. However, structure elucidation of sulfur-containing compounds by ESI-MS (Gao et al., 2006; Surratt et al., 2007a, Iinuma et al., 2007a, b) or FTIR spectrometry (Blando et al., 1998; Gilardoni et al., 2007), and determination of elemental compositions of a large number of organic species by ultra high-resolution ion cyclotron resonance mass spectrometry in continental aerosol (Reemtsma et al., 2006; Schmitt-Kopplin et al., manuscript in preparation) all imply that sulfate esters (organosulfates) and their derivatives may be the dominant form of organic sulfur compounds in water-soluble continental aerosol. This assumption is also supported by several smog-chamber studies which observed the formation of organosulfates during the photooxidation of various volatile organic compounds in the presence of acidic seed aerosols or $\mathrm{SO}_{2}$. From the available data on TC on each stage, it is possible to estimate which fraction of TC can be attributed to organosulfates. However, it can only be done with a very high level of uncertainty, since a mass-weighted average MW (or rather $\mathrm{C} / \mathrm{S}$ ratio) of all organosulfates would be needed, preferably for each stage. However, organosulfate speciation measurements have been 
so far only qualitative and cannot provide the required information. Among hitherto identified organosulfate compounds, $\mathrm{C}$ to $\mathrm{S}$ molar ratio ranges from 2:1 (sulfate ester of glyoxal) to 10:1 (e.g. sulfate ester of pinonaldehyde). Using an average ratio of $6: 1$ we obtain that the contribution of organosulfates to the total carbonaceous aerosol mass can be in between 8 and 50\% with a very high level of uncertainty.

\subsection{Size distribution of organic sulfur}

The measured mass concentrations of total (bulk) sulfur and sulfate-methanesulfonate ions on each impactor stage of the fine particle size range are shown in Fig. 2, with their corresponding uncertainties. As far as the origin of organosulfates is concerned, both the magnitude of mass concentration of organosulfates and their size distribution imply a potential formation mechanism. In the nucleation mode virtually no excess sulfur was found within the range of uncertainty. However, due to the fact that on the first stage the amounts were close to the detection limits and uncertainty ranges were thus quite extensive, this statement is supported by the very low levels of excess sulfate that were found on the second and third stages of the impactor (with amounts well above the detection limits).This finding may imply that the reactive uptake of unsaturated volatile organic compounds or their gas-phase photooxidation products on freshly formed highly acidic particles may not be a significant process on a mass basis. Both absolute and relative (to sulfate) mass concentrations of organosulfates peaked in the accumulation mode particles, in the range in which the effective surface size distribution of fine aerosol is typically at its maximum. In this range the uncertainties associated with organosulfate mass concentrations are the lowest due to the fact that the uncertainty ranges of the measured concentrations do not overlap. Thus a possible heterogeneous mechanism of organosulfate formation is the partitioning of semivolatile carbonyl compounds with subsequent or concurrent condensation of sulfuric acid formed in gas-phase photooxidation reactions, and chemical reactions on the particle surface producing a refractory organic film. There was an indication in a previous transmission electron microscopic study on accumulation mode summertime aerosol from the same site (Pósfai and Molnár, 2000) that such films do exist on typical ammonium-sulfate particles and can withstand the electron beam and high vacuum of the electron microscope. This reaction mechanism exerts no driving force for significant direct uptake of isoprene or monoterpenes, thus organosulfate formation should be preceded by gas-phase photooxidation reactions producing semi-volatile carbonyl compounds or other oxygen-containing compounds such as $\beta$-pinene oxide and pinanediol (Iinuma et al., 2007b) which are capable of partitioning into the aerosol phase. Esterification reactions on the surface provide a continuous sink for these semi-volatile carbonyls and thus lead to significant SOA formation compared to physical partitioning. However, recent work by Surratt et al. (2006, 2007a) and Ng et al. (2008) has shown that organosulfates and nitrooxy-organosulfates of isoprene can form in the presence of non-acidified sulfate seed aerosol which may indicate that other currently unknown mechanisms could also be operative.

\section{Conclusion}

In this work, as likely the very first attempt to quantify organosulfates in ambient aerosol, we inferred the mass concentrations of organic sulfur by difference from concurrently determined mass concentrations of total sulfur, sulfate and methanesulfonate in size-segregated rural fine aerosol. Based on chemical information available in the literature, we assumed that most of the organic sulfur compounds were likely organic sulfate esters (organosulfates). Admitting that the uncertainties accompanying the indirect determination were relatively large, we found that mass concentrations of organosulfates in water-soluble rural fine aerosol ranged from $0.02 \mu \mathrm{gS} \mathrm{m}^{-3}$ to $0.09 \mu \mathrm{gS} \mathrm{m}^{-3}$ yielding a mass contribution of $6-12 \%$ to bulk sulfur concentrations (or 6-14\% to sulfate concentrations). Since sulfate is soluble in water but some part of organosulfates (e.g. high MW species) may not be, these values likely represent a lowerbound estimate for the organosulfate contribution. The inferred size distribution of organosulfates suggested that they possibly formed in heterogeneous reactions from semi-volatile carbonyl compounds with subsequent or concurrent condensation of gaseous sulfuric acid producing a refractory organic film on particle surfaces.

Since the number of samples was very limited and sampling was confined to a single location and time-period, the tropospheric abundance of this compound class cannot be reliably assessed. However, our results suggest, in line with conclusions drawn from specific qualitative ambient aerosol measurements as well as implicitly from smog chamber studies, that organosulfates may represent a substantial mass fraction of the hitherto unknown part of SOA in rural aerosol in summer. Furthermore, the sulfur bound in these compounds add a sizable mass to the sulfur bound as sulfate, and thus it might not be overlooked in the global sulfur budget. However in these fields further studies are clearly warranted.

Acknowledgements. The authors are grateful to Mrs. Mihály Szauer and Mrs. Katalin Galló-Békefi for their help in the experimental work. The financial supports of the Hungarian Science Foundation (OTKA TS049845 and OTKA PF63770) and the János Bolyai Research Fellowship of the Hungarian Academy of Sciences are also gratefully acknowledged.

Edited by: Y. Rudich 


\section{References}

Blando, J. D., Porcja, R. J., Li, T. H., Bowman, D., Lioy, P. J., and Turpin, B. J.: Secondary formation and the Smoky Mountain organic aerosol: an examination of aerosol polarity and functional group composition during SEAVS, Environ. Sci. Technol., 32, 604-613, 1998.

Czoschke, N. M. and Jang, M.: Effect of acidity parameters on the formation of heterogeneous aerosol mass in the $\alpha$-pinene ozone reaction system, Atmos. Environ., 40, 5629-5639, 2006.

Czoschke, N. M., Jang, M. and Kamens, R. M.: Effect of acidic seed on biogenic secondary organic aerosol growth, Atmos. Environ., 37 (30), 4287-4299, 2003.

Edney, E. O., Kleindienst, T. E., Jaoui, M., Lewandowski, M., Offenberg, J. H., Wang, W., and Claeys, M.: Formation of 2methyltetrols and 2-methylglyceric acid in secondary organic aerosol from laboratory irradiated isoprene/NOx/SO2/air mixtures and their detection in ambient $\mathrm{PM}_{2.5}$ samples collected in the eastern United States, Atmos. Environ., 39(29), 5281-5289, 2005.

Felinger, A.: Data Analysis and Signal Processing in Chromatography, Data Handling in Science and Technology, Elsevier, Amsterdam, 21, 331-383, 1998.

Gao, S., Keywood, M., Ng, N. L., Surratt, J., Varutbangkul, V., Bahreini, R., Flagan, R. C. and Seinfeld, J. H.: Low-molecularweight and oligomeric components in secondary organic aerosol from the ozonolysis of cycloalkenes and alpha-pinene, J. Phys. Chem. A, 108(46), 10147-10164, 2004a.

Gao, S., Surratt, J. D., Knipping, E. M., Edgerton, E. S., Shahgholi, M., and Seinfeld, J. H.: Characterization of polar organic components in fine aerosols in the southeastern United States: identity, origin, and evolution, J. Geophys. Res., 111(D14), D14314, 2006.

Gao, S., Ng, N. L., Keywood, M., Varutbangkul, V., Bahreini, R., Nenes, A., He, J., Yoo, K. Y., Beauchamp, J. L., Hodyss, R. P., Flagan, R. C., and Seinfeld, J. H.: Particle phase acidity and oligomer formation in secondary organic aerosol, Environ. Sci. Technol. 38(24), 6582-6589, 2004b.

Gilardoni S., Russell, L. M., Sorooshian, A., Flagan, R. C., Seinfeld, J. H., Bates, T. S., Quinn, P. K., Allan, J. D., Williams, B., Goldstein, A. H., Onasch, T. B., Worsnop, D. R.: Regional variation of organic functional groups in aerosol particles on four US east coast platforms during the International Consortium for Atmospheric Research on Transport and Transformation 2004 campaign, J. Geophys. Res., 112, D10S27, doi:10.1029/2006JD7737, 2007.

Gómez-González, Y., Surratt, J. D., Cuyckens, F., Szmigielski, R., Vermeylen, R., Jaoui, M., Lewandowski, M., Offenberg, J. H., Kleindienst, T. E., Edney, E. O., Blockhuys, F., Van Alsenoy, C., Maenhaut, W., and Claeys, M.: Characterization of organosulfates from the photooxidation of isoprene and unsaturated fatty acids in ambient aerosol using liquid chromatography/(-) electrospray ionization mass spectrometry, J. Mass Spectrom., 43, 371-382, 2008.

Iinuma, Y. Müller, C., Böge, O., Gnauk, T., and Herrmann, H.: The formation of organic sulfate esters in the limonene ozonolysis secondary organic aerosol (SOA) under acidic conditions, Atmos. Environ., 41, 5571-5583, 2007a.

Iinuma, Y., Müller, C., Berndt, T., Böge, O., Claeys, M., and Herrmann, H.: Evidence for the existence of organosulfates from beta-pinene ozonolysis in ambient secondary organic aerosol, Environ. Sci. Technol., 41, 6678-6683, 2007b.

Iinuma, Y., Böge, O., Gnauk, T., and Herrmann, H.: Aerosolchamber study of the alpha-pinene/O-3 reaction: influence of particle acidity on aerosol yields and products, Atmos. Environ., 38(5), 761-773, 2004.

Jang, M. S. and Kamens, R. M.: Atmospheric secondary aerosol formation by heterogeneous reactions of aldehydes in the presence of a sulfuric acid aerosol catalyst, Environ. Sci. Technol., 35 (24), 4758-4766, 2001.

Jang, M. S., Carroll, B., Chandramouli, B., and Kamens, R. M.: Particle growth by acid-catalyzed heterogeneous reactions of organic carbonyls on preexisting aerosols, Environ. Sci. Technol., 37, 3828-3837, 2003.

Jang, M. S., Czoschke, N. M., and Northcross, A. L.: Atmospheric organic aerosol production by heterogeneous acid-catalyzed reactions, Chem. Phys. Chem, 5, 1647-1661, 2004.

Jang, M. S., Czoschke, N. M., and Northcross, A. L.: Semiemperical model for organic aerosol growth by acid-catalyzed heterogeneous reactions of organic carbonyls, Environ. Sci. Technol., 39, 164-174, 2005.

Jang, M. S., Czoschke, N. M., Northcross, A. L., and Cao, G.: SOA formation from partitioning and heterogeneous reactions: model study in the presence of inorganic species, Environ. Sci. Technol., 40, 3013-3022, 2006.

Jang, M. S., Czoschke, N. M., Lee, S., and Kamens, R. M.: Heterogeneous atmospheric aerosol production by acid-catalyzed particle-phase reactions, Science, 298(5594), 814-817, 2002.

Kleindienst, T. E., Edney, E. O., Lewandowski, M., Offenberg, J. H., and Jaoui, M.: Secondary organic carbon and aerosol yields from the irradiations of isoprene and $\alpha$-pinene in the presence of $\mathrm{NO}_{\mathrm{x}}$ and $\mathrm{SO}_{2}$, Environ. Sci. Technol., 40, 3807-3812, 2006.

Kouvarakis, G. and Mihalopoulos, N.: Seasonal variation of dimethylsulfide in the gas phase and of methanesulfonate and non-sea-salt sulfate in the aerosols phase in the Eastern Mediterranean atmosphere, Atmos. Environ., 36, 929-938, 2002.

Kroll, J. H. and Seinfeld, J. H.: Chemistry of secondary organic aerosol: Formation and evolution of low-volatility organics in the atmosphere, Atmos. Environ., 42(16), 3593-3624, 2008.

Kroll, J. H., Ng, N. L., Murphy, S. M., Varutbangkul, V., Flagan, R. C., and Seinfeld, J. H.: Chamber studies of secondary organic aerosol growth by reactive uptake of simple carbonyl compounds, J. Geophys. Res. 110, D23207, doi:10.1029/2005JD006004, 2005.

Liggio, J., Li, S. M., and Mclaren, R.: Heterogeneous reactions of glyoxal on particulate matter: identification of acetals and sulfate esters, Environ. Sci. Technol., 39(6), 1532-1541, 2005.

Liggio, J., Li, S. M., Brook, J. R., and Mihele, C.: Direct polymerization of isoprene and alpha-pinene on acidic aerosols, Geophys. Res. Lett., 34, L05814, doi:10.1029/2006GL028468, 2007.

Liggio, J., Li, S. M.: Organosulfate formation during the uptake of pinonaldehyde on acidic sulfate aerosols. Geophys. Res. Lett., 33(13), L13808, doi:10.1029/2006GL026079, 2006 b.

Liggio, J., Li, S. M.: Reactive uptake of pinonaldehyde on acidic aerosols, J. Geophys. Res. 111, D24303, doi:10.1029/2005JD006978, 2006a.

Limbeck, A., Kulmala, M. and Puxbaum, H.: Secondary organic aerosol formation in the atmosphere via heterogeneous reaction of gaseous isoprene on acidic particles, Geophys. Res. Lett., 
30(19), doi:10.1029/2003/GL017738, 2003.

Mihalopoulos, N., Kerminen, V. M., Kanakidou, M., Berresheim, H., Sciare, J.: Formation of particulate sulfur species (sulfate and methanesulfonate) during summer over the Eastern Mediterranean: A modelling approach, Atmos. Environ., 41, 6860-6871, 2007.

Ng, N. L., Kwan, A. J., Surratt, J. D., Chan, A. W. H., Chhabra, P. S., Sorooshian, A., Pye, H. O. T., Crounse, J. D., Wennberg, P. O., Flagan, R. C., and Seinfeld, J. H.: Secondary organic aerosol (SOA) formation from reaction of isoprene with nitrate radicals (NO3), Atmos. Chem. Phys., 8, 4117-4140, 2008, http://www.atmos-chem-phys.net/8/4117/2008/.

Northcross, A. L. and Jang, M.: Heterogeneous SOA yield from ozonolysis of monoterpenes in the presence of inorganic acid, Atmos. Environ., 41(7), 1483-1493, 2007.

Ocskay, R., Salma, I., Wang, W., and Maenhaut, W.: Characterization and diurnal variation of size-resolved inorganic watersoluble ions at a rural background site, J. Environ. Monitor., 8, 300-306, 2006.

Pósfai, M. and Molnár, A.: Aerosol particles in the troposphere: A mineralogical introduction, EMU Notes in Mineralogy, 2, 197252, 2000.

Quinn, P. K., Bates, T. S., Coffman, D. J., Miler, T. L., Johnson, J. E., Covert, D. S., Putaud, J. P., Neusüß, C., and Novakov, T.: A comparison of aerosols chemical and optical properties from the first and the second aerosol characterization experiment, Tellus 52B, 239-257, 2000.

Ravishankara, A. R.: Heterogeneous and multiphase chemistry in the troposphere, Science, 276(5315), 1058-1065, 1997.

Reemtsma, T., These, A., Venkatachari, P., Xia, X., Hopke, P. K., Springer, A., and Linscheid, M.: Identification of fulvic acids and sulfated and nitrated analogues in atmospheric aerosol by electrospray ionization Fourier transform ion cyclotron resonance mass spectrometry, Anal. Chem., 78(24), 8299-8304, 2006.
Romero, F. and Oehme, M.: Organosulfates-a new component of humic-like substances in atmospheric aerosols?, J. Atmos. Chem., 52, 283-294, 2005.

Surratt, J. D., Lewandowski, M., Offenberg, J. H., Jaoui, M., Kleindienst, T. E., Edney, E. O., and Seinfeld, J. H.: Effect of acidity on secondary organic aerosol formation from isoprene, Environ. Sci. Technol., 41(15), 5363-5369, 2007 b.

Surratt, J. D., Murphy, S. M., Kroll, J. H., Ng, N. L., Hildebrandt, L., Sorooshian, A., Szmigielski, R., Vermeylen, R., Maenhaut, W., Claeys, M., Flagan, R. C., and Seinfeld, J. H.: Chemical composition of secondary organic aerosol formed from the photooxidation of isoprene, J. Phys. Chem. A, 110(31), 9665-9690, 2006.

Surratt, J. D., Kroll, J. H., Kleindienst, T. E., Edney, E. O., Claeys, M., Sorooshian, A., Ng, N. L., Offenberg, J. H., Lewandowski, M., Jaoui, M., Flagan, R. C., and Seinfeld, J. H.: Evidence for organosulfates in secondary organic aerosol, Environ. Sci. Technol., 41(2), 517-527, 2007.

Szilágyi, V. and Hartyáni, Z.: Development of an X-ray fluorescence spectrometric method for the analysis of atmospheric aerosol samples, Microchem. J., 79, 37-41, 2005.

Tolocka, M. P., Jang, M., Ginter, J. M., Cox, F. J., Kamens, R. M., and Johnston, M. V.: Formation of oligomers in secondary organic aerosol, Environ. Sci. Technol., 38(5), 2105-2115, 2004.

von Glasow, R. and Crutzen, P. J.: Model study of multiphase DMS oxidation with a focus on halogens, Atmos. Chem. Phys., 4, 589608, 2004, http://www.atmos-chem-phys.net/4/589/2004/. 